there is 'a solid basis for optimism' concerning the effectiveness of integrated treatment. This book will have achieved much if it can help reduce the pessimism that is too frequently expressed in the context of 'dual diagnosis'. Even when treating people who appear at first completely wayward, a patient and collaborative approach can in the end be immensely rewarding

Tom Carnwath Clinical Director, Pierremont Unit, Darlington Memorial Hospital, Hollyhurst Road, Darlington DL3 6HX

\section{The Ethical Attitude in Analytic Practice}

Hester McFarland Solomon \& Mary Twyman (eds) London: Free Association Books, 2003, 184 pp., f18.99 pb, ISBN: 1853435589

Ethics is the discourse of 'ought' and 'should'. The values of medicine have swung away from an attitude of uncritical paternalism to a more considered position which acknowledges the complexity of all therapeutic relationships; a complexity that is a function of factors such as time, depth and mutuality (Cox, 1976). Psychoanalysis, which started as a branch of medicine, therefore needs to consider and review its ethical identity, and this book is

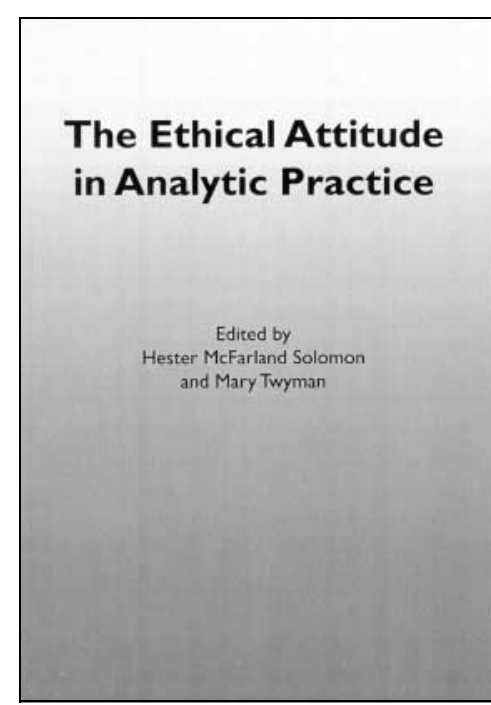

a collection of papers by therapists who offer a largely (although not exclusively) Jungian view of ethical issues in psychoanalytic practice.

One of the complications of this subject is that ethical thinking (by which I mean the process of reasoning about dilemmas of 'ought' and 'should' in clinical practice) overlaps with clinical thinking in psychotherapy. There is often no distinction between the clinical and the ethical; the fact and the value, as it were. It can therefore be hard for analysts not to impose their own value systems onto patients in the name of health, and this is why it is hard to argue that psychoanalysis is a purely therapeutic activity.

Some of the contributors to this book offer valuable reflections on this complicated theme. I particularly liked the chapters on confidentiality, and McKenna's chapter for its clear and compassionate voice. Sher's chapter about ethics and organisations is one that I will definitely be sharing with trainees and colleagues. Overall, I would recommend the book, especially to trainers of therapists and to trainees in psychiatry who want to know more about being a psychotherapist.

The only thing I disliked was the occasionally pompous and patronising tone taken about patients' resistance to therapy, since it seems to me that the perception of 'resistance' itself represents a type of ethical judgement by the therapist. Reading this book also made me sad that it seems impossible for the different schools of psychoanalysis and psythotherapy to talk to each other and integrate their ethical visions, or at least to set out their similarities and differences in a comprehensive way.

COX, M. (1976) Structuring the Therapeutic Encounter: Compromise with Chaos. London: Jessica Kingsley.

Gwen Adshead Consultant Psychotherapist, Broadmoor Hospital, Crowthorne RG45 7EG

\title{
miscellany
}

\section{Royal Medical Benevolent Fund}

The Royal Medical Benevolent Fund (RMBF) is a registered charity that provides support to doctors and their dependants who have fallen on hard times. Tragedy can strike unexpectedly and all too often does - not least to younger members of the profession and their families. For well over 100 years, the RMBF has been there to help in times of need, and never is that need more evident than at Christmas time. A seasonal gift can transform a rather cheerless Christmas into a very happy one. The 2003 Christmas appeal raised f90 000 and it is very much hoped that this sum will be exceeded in 2004
Please consider making a donation and brighten Christmas 2004 for many less fortunate colleagues and their dependants. Contributions may be sent to the Royal Medical Benevolent Fund, 24 King's Road, Wimbledon, London SW19 80N, or to the Treasurer of your local guild of this Fund. For further information please visit http:// www.rmbf.org. 